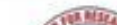 secogosout $R E A D S$ Review of Economics Sustainable Solutions and Development Studies Journal homepage: http://reads.spcrd.org \\ ISSN (Print): 2519-9692 \\ ISSN (Online): 2519-9706
}

\section{The Lucas Paradox and Institutional Quality: Evidence from Emerging Markets}

${ }^{a}$ Muhammad Atiq-ur-Rehman, ${ }^{\mathrm{b}}$ Allah Ditta, ${ }^{\mathrm{c}}$ Muhammad Atif Nawaz, ${ }^{\mathrm{d}}$ Furrukh Bashir

${ }^{a}$ Assistant Professor of Economics, Higher Education Department, Government of the Punjab Lahore, Pakistan Email: atiq164@live.com

${ }^{\mathrm{b}}$ Assistant Professor of Economics, Higher Education Department, Government of the Punjab Lahore, Pakistan

${ }^{c}$ Lecturer, Department of Economics, The Islamia University of Bahawalpur, Pakistan Email: atif.nawaz.baloch@gmail.com

${ }^{\mathrm{d}}$ Assistant Professor, School of Economics, Bahauddin Zakariya University, Multan, Pakistan

Email: furrukh@bzu.edu.pk

\begin{tabular}{l}
\hline ARTICLE DETAILS \\
History: \\
Accepted 23 May 2020 \\
Available Online 15 June 2020
\end{tabular}

\section{Keywords:}

Lucas Paradox; Institutions, Capital Flows; Foreign Direct Investment

JEL Classification:

F21, F34, F41, F2

DOI: $10.47067 /$ reads.v6i2.223

\begin{abstract}
The neoclassical theory illustrates that the capital will flow from the capital-rich economies towards the capital-poor states. However, it is generally observed that the capital does not move from high-income to low-income economies. This contradictory behavior of global capital flows is called the Lucas paradox. According to Alfaro, Kalemli-Ozcan, \& Volosovych ( $A K V)$ model, the Lucas paradox can be entirely explained by the institutional quality. In the light of $A K V$ notion, this paper examines the role of institutional quality in explaining the Lucas paradox. The empirical analysis involves 17 major emerging economies of the world by using panel data for the period 1999-2018. The GMM estimation reveals that the Lucas paradox is explained by the institutional quality in case of FDI flows only. However, institutional quality indicators generally remain unable to explain the paradox in case of portfolio equity capital flows. Moreover, financial development is found to be a significant determinant of portfolio equity flows in the emerging markets. Finally, we suggest that the financial flows to the emerging markets are sensitive to the nature of the capital flows.
\end{abstract}

(C) 2020 The authors. Published by SPCRD Global Publishing. This is an open access article under the Creative Commons Attribution-

NonCommercial 4.0

Corresponding author's email address: furrukh@bzu.edu.pk

\section{Introduction}

There are two different schools of thought explaining the impact of capital account openness on capital flows across countries, first neoclassical theory and second the Lucas paradox. According to the neoclassical view, liberalization of capital flows should cause capital to move from the rich nations to the poor ones. The marginal product of capital (MPK) tends to be higher in low-income countries due to lack of capital. The differences in the MPK should incentivize the investors to invest in low-income 


\section{Review of Economics and Development Studies, Vol. 6 (2) 2020, 461-470}

economies.

In this regard, Robert Lucas (1990) tested the neoclassical theory by using the data of the US and India for the period 1909-1958. Although MPK in India was found to be 58 times greater than that of the USA, the capital was not allocated accordingly. Based on his findings, Lucas questioned the validity of the neoclassical model, explaining the beneficial impacts of financial globalization. Many researchers tried to explain these contradictory findings, namely Lucas paradox. The explanations of the paradox can be divided into two categories. The first category is based on the differences in the production structures of the economies. These can be production technology, government policies and institutional quality. The second category includes global capital market imperfections comprising sovereign credit risk and information asymmetry.

The empirical research suggests that the most imperative factor in the explanation of the Lucas Paradox is the quality of institutions. The literature on the nexus between institutional quality and economic performance asserts that states with better institutions, non-corrupt governments and civil liberties attract more foreign capital and achieve higher levels of development (North, 1990; Rodrik, 2000; Acemoglu et al., 2005). The quality of a country's institutions is the primary determinant of capital flows (Alfaro et al., 2008; Akhtaruzzaman, 2017). The institutional quality influences investor's sentiment and promotes portfolio and direct investment inflows. Likewise, Faria and Mauro (2009) explain that equity capital is more attracted to countries with better institutions. The poor institutional quality with bad law and order situation leave the productive potentials unexploited (Parente \& Prescott, 1994). The poor law enforcement and weak property rights with other uncertain socio-economic conditions deter foreign investors and hinder the capital flows. In this regard, Ju and Wei (2014) assert that the bureaucratic corruption and miserable state of property rights discourage inflows of FDI. Moreover, Acemoglu et al. (2005) and Alfaro et al. (2007) explain that the major cause of differences in capital flows across nations is the differences in property rights protection. Most prominently, a seminal study by Alfaro, Kalemli-Ozcan, \& Volosovych (AKV) suggests that the contradictory behavior of global capital flows can be entirely explained by institutional quality. This paper aims at evaluating the AKV notion by empirically examining the role of institutional quality in explaining the Lucas paradox.

\section{Literature Review}

The theoretical literature points out some major factors responsible for the cross border capital movements. These factors include the quality of human capital (Lucas, 1990), differences in technology (Eichengreen \& park, 2003), and functioning of the institutional system (Alfaro et al., 2008). Other studies suggest some additional factors, including the risk of sovereign default (Reinhart \& Rogoff, 2004), state regulations and organizational structures (Hall \& Jones, 1999). These determinants of capital flows can influence economic performance through changes in investment and total factor productivity.

Alfero et al. (2007) use cross-country regressions to examine a data set spanning from 1971 to 1998. The researchers find that institutional quality is the pivotal feature in the explanation of the Lucas paradox. The authors are of the view that the differences in human capital and asymmetric information can also influence capital flows, but these factors cannot fully explain the paradox. Similarly, Goldin and Reinert (2007) explain that the lower global interest rates, the degree of openness and institutional quality are the significant determinants of financial flows. Also, Caselli and Feyrer (2007) identify some measurement hitches responsible for the Lucas paradox. Moreover, Alfaro et al. (2008) empirically analyze the data and elucidate that the institutional quality is the core variable in resolving the Lucas paradox. Likewise, Gourinchas and Jeanne (2009) notice that the capital flows have a tendency to flow 


\section{Review of Economics and Development Studies, Vol. 6 (2) 2020, 461-470}

more towards the countries which are at the initial stages of development.

The wobbly policies in the industrial countries are a vital determinant of capital flows to the EMEs (IMF, 2011). Byrne and Fiess (2011) explain that the US interest rates are an important factor affecting the global capital flows to the emerging economies. Ghosh et al. (2014) point out different factors supporting a capital surge to the EMEs, including global risk appetite returns to investment and the US interest rates. According to Restucia and Rogerson (2008) Hsieh and Klenow (2009), and Monge-Naranjo, Sanchez and Llopis (2019), the differences in MPK are a major determinant of capital flows. Several other studies declare the institutional quality as a major factor affecting the cross border capital flows, including Faria and Mauro (2009), and Daude and Fratzscher (2008).

Edison and Warnock (2008) find no significant association between the International Country Risk Guide (ICRG) composite index and the US purchases of portfolio equity securities of emerging Asia and Latin America. Also, Azemar and Desbordes (2013) find that the quality of institutions is important but cannot completely explain the Lucas puzzle. Further, Ahmed and Zalate (2014) point out that the global risk appetite and differences in growth rates and interest rates significantly affect private capital flows between advanced and emerging economies. Likewise, Göktan (2015) uses quantile regression analysis to explore that the institutional system can better explain the Lucas paradox after controlling for the country heterogeneity. Martin (2018) examines the new classical view of capital flows in Asian economies during 1980-2016. Using the fixed-effects estimation method, he finds that the poor countries experience more capital inflows while the rich economies experience more capital outflows. The empirical results confirm the new classical theory of capital flows.

\section{Empirical Estimation and Data}

This study focuses on the explanation of the Lucas paradox mainly by incorporating the quality of institutions in the regression analysis. The empirical literature has declared that institutions are the significant determinants of capital flows across nations. In the spirit of AKV model, we estimate the following modified econometric specification:

$$
\log F_{i t}=\alpha \log Y_{i, t_{-}}+\beta X_{i t}+\gamma Q_{i t}+\mu_{i t}
$$

Where $\log$ symbolizes natural logarithm, $F$ is the foreign capital flows categorized as net inflows of Portfolio equity capital and FDI inflows interchangeably. The alphabet $Y$ is the initial GDP per capita, referring to the year 1999. The notation $X$ embodies control variables, including average years of secondary schooling, a capital account openness index, and private credit as a proxy for financial development. We, especially incorporate financial development as a control variable in the model to examine the role of a developed banking sector in enticing foreign capital. The average institutional quality (IQ) is represented by the Worldwide Governance Indicators (WGI). The error term is denoted by $\mu_{i t}$ and the alphabets $i$ and $t$ indicate country and time, respectively.

The AKV model and some other empirical findings suggest that institutions play a pivotal role in boosting capital inflows. We slightly modify the general AKV specification to incorporate the financial development as a control variable to examine whether a developed banking sector can explain the Lucas paradox or not.

The data on net inflows of Portfolio equity capital, net inflows of FDI as a percentage of GDP and average schooling years at secondary level comes from the World Bank's World Development Indicators (WDI). The KAOPEN index represents capital account openness, and the data is provided by Chinn and 


\section{Review of Economics and Development Studies, Vol. 6 (2) 2020, 461-470}

Ito (2006). Private credit by deposit money banks as a percentage of GDP is obtained from the financial structure database of the World Bank. The data on institutional quality is obtained from the Worldwide governance indicators provided by the World Bank. Following Daude and Stein (2007), we adopt the method of combining the WGI variables by summing them up. Capturing the variables into one composite index enables us to get one aggregate component having various dimensions. WGI- 6 is the sum of all the governance indicators, including voice and accountability, political stability, government effectiveness, regulatory quality, the rule of law, and control of corruption. WGI-3 is the sum of three important indicators involving regulatory quality (RQ), the rule of law (RL), and control of corruption (CC). In addition, we have individually incorporated the three aforementioned indicators of institutional quality in the regressions to examine the consistency of empirical estimation. All WGI indicators have a range of estimated values between +2.5 and -2.5 . The value +2.5 indicates a strong position of governance, and the value $-\mathbf{2 . 5}$ implies weak governance.

The role of institutions and banking sector development in explaining the Lucas paradox is empirically examined for the seventeen major emerging economies of the World including Argentina, Brazil, Chile, China, Hungary, India, Indonesia, Malaysia, Mexico, Pakistan, Philippines, Poland, Russia, Thailand, Turkey, Ukraine, and Venezuela. A panel data sample for the period 1999-2018 is used for the empirical analysis. The data is transformed in 5-year averages to minimize the cyclical fluctuations. Generalized Method of Moments (GMM) seems to be a suitable method for estimation as it has the advantage of controlling the endogeneity problem. We use modified and more sophisticated estimation technique namely, system GMM introduced by Arellano and Bover (1995) and Blundell and Bond (1997). According to Bond et al. (2001), the system GMM has a feature of combining the previous set of equations in first differences with appropriately lagged levels as instrumental variables with additional equations set in the level form with proper lagged first differences as instrumental variables. The validity of instruments is evaluated by the Hansen test of over-identifying restrictions. The serial correlation problem is detected by using the Arellano \& Bond test for second-order serial correlation (ABm2). If GMM system estimates are not subject to second-order serial correlation, then the validity of instruments is confirmed, and the estimates ensure efficiency and consistency. The application of robust system GMM controls the empirical estimation for heteroscedasticity by providing robust or adjusted standard errors.

\subsection{Empirical Results}

The system GMM estimation results are presented below in Table 3.1-A and Table 3.1-B, respectively. 


\begin{tabular}{|c|c|c|c|c|c|}
\hline \multirow{2}{*}{\multicolumn{6}{|c|}{$\begin{array}{l}\text { Table: 3.1-A Portfolio Equity Capital Flows and th } \\
\text { Dependent variable: Portfolio equity, net inflows }\end{array}$}} \\
\hline & & & & & \\
\hline Regression & \multirow{2}{*}{\begin{tabular}{|l|}
$(1)$ \\
$1.1396^{* \star}$ \\
$(0.5496)$
\end{tabular}} & \multirow{2}{*}{$\begin{array}{l}(2) \\
1.1149^{* *} \\
(0.5242)\end{array}$} & \multirow{2}{*}{$\begin{array}{l}(3) \\
1.2364^{* *} \\
(0.5178)\end{array}$} & \multirow{2}{*}{$\begin{array}{l}(4) \\
1.0432^{* *} \\
(0.5040)\end{array}$} & \multirow{2}{*}{$\begin{array}{l}(5) \\
1.0996^{* *} \\
(0.5088)\end{array}$} \\
\hline $\begin{array}{lll}\begin{array}{l}\text { Initial } \\
\text { capita }\end{array} & \text { GDP per }\end{array}$ & & & & & \\
\hline Schooling & $\begin{array}{l}2.3276 \\
(2.8749)\end{array}$ & $\begin{array}{l}2.334 \\
(2.7834)\end{array}$ & $\begin{array}{l}1.7984 \\
(2.6117)\end{array}$ & $\begin{array}{l}2.7108 \\
(2.786)\end{array}$ & $\begin{array}{l}2.5002 \\
(2.6896)\end{array}$ \\
\hline KAOPEN & $\begin{array}{l}-0.5823 \\
(0.3702)\end{array}$ & $\begin{array}{l}-0.5601 \\
(0.3735)\end{array}$ & $\begin{array}{l}-0.4069 \\
(0.3451)\end{array}$ & $\begin{array}{l}-0.6363^{* * *} \\
(0.3830)\end{array}$ & $\begin{array}{l}-0.6475^{* * *} \\
(0.3765)\end{array}$ \\
\hline Credit & $\begin{array}{l}1.8879 * \\
(0.3796)\end{array}$ & $\begin{array}{l}1.9449 * \\
(0.3876)\end{array}$ & $\begin{array}{l}2.0163^{*} \\
(0.3639)\end{array}$ & $\begin{array}{l}1.9073^{*} \\
(0.3956)\end{array}$ & $\begin{array}{l}1.8659^{*} \\
(0.4058)\end{array}$ \\
\hline $\begin{array}{l}\text { Institutional } \\
\text { quality } \\
\text { WGI-6 }\end{array}$ & $\begin{array}{l}-0.1062 \\
(0.0820)\end{array}$ & & & & \\
\hline $\begin{array}{l}\text { Institutional } \\
\text { quality } \\
\text { WGI-3 }\end{array}$ & & $\begin{array}{l}-0.3287 \\
(0.2235)\end{array}$ & & & \\
\hline $\begin{array}{l}\text { Regulatory quality } \\
\text { (RQ) }\end{array}$ & & & $\begin{array}{l}-1.4114^{* *} \\
(0.5067)\end{array}$ & & \\
\hline Rule of law (RL) & & & & $\begin{array}{l}-0.7280 \\
(0.7355)\end{array}$ & \\
\hline $\begin{array}{ll}\text { Control of } \\
\text { Corruption (CC) }\end{array}$ & & & & & $\begin{array}{l}-0.7361 \\
(0.5724)\end{array}$ \\
\hline $\begin{array}{l}\text { Hansen } \\
\text { value }]\end{array}$ & 1.000 & 0.999 & 1.000 & 0.999 & 1.000 \\
\hline ABm2 [P-value] & 0.070 & 0.079 & 0.084 & 0.069 & 0.062 \\
\hline Observations & 51 & 51 & 51 & 51 & 51 \\
\hline \multicolumn{6}{|c|}{$\begin{array}{l}\text { Note: The data sample ranges from } 1999 \text { to } 2018 \text { with 5-year non-overlapping averages. All } \\
\text { variables are in log form except the KAOPEN index and institutional quality indicators. One-step } \\
\text { robust system GMM dynamic panel estimator of Arellano and Bond (1991) is used for estimation. } \\
\text { Robust standard errors are presented in parentheses; }{ }^{* *} \text {. and } * * * \text { indicate significance at } 1 \% \text {, } \\
5 \% \text {, and } 10 \% \text { levels, respectively. }\end{array}$} \\
\hline
\end{tabular}




\begin{tabular}{|c|c|c|c|c|c|}
\hline \multicolumn{6}{|c|}{ Table: 3.1-B FDI Flows and the Lucas Paradox } \\
\hline \multicolumn{6}{|c|}{ Dependent variable: FDI Inflows } \\
\hline Regression & (1) & (2) & (3) & (4) & (5) \\
\hline $\begin{array}{lll}\text { Initial } & \text { GDP } & \text { per } \\
\text { capita } & & \end{array}$ & $\begin{array}{l}-0.0256 \\
(0.0895)\end{array}$ & $\begin{array}{l}-0.0007 \\
(0.0945)\end{array}$ & $\begin{array}{l}-0.0148 \\
(0.0946)\end{array}$ & $\begin{array}{l}-0.0334 \\
(0.1019)\end{array}$ & $\begin{array}{l}-0.01885 \\
(0.0966)\end{array}$ \\
\hline Schooling & $\begin{array}{l}0.3790 \\
(0.4412)\end{array}$ & $\begin{array}{l}0.3006 \\
(0.4673)\end{array}$ & $\begin{array}{l}0.3083 \\
(0.4212)\end{array}$ & $\begin{array}{l}0.1540 \\
(0.5135)\end{array}$ & $\begin{array}{l}0.3599 \\
(0.5102)\end{array}$ \\
\hline KAOPEN & $\begin{array}{l}0.0262 \\
(0.0626)\end{array}$ & $\begin{array}{l}0.0270 \\
(0.0735)\end{array}$ & $\begin{array}{l}0.0270 \\
(0.0729)\end{array}$ & $\begin{array}{l}0.0376 \\
(0.801)\end{array}$ & $\begin{array}{l}0.0196 \\
(0.0836)\end{array}$ \\
\hline Credit & $\begin{array}{l}0.1422^{* * *} \\
(0.0800)\end{array}$ & $\begin{array}{l}1.1213 \\
(0.0927)\end{array}$ & $\begin{array}{l}0.1209 \\
(0.0984)\end{array}$ & $\begin{array}{l}0.1223 \\
(0.1030)\end{array}$ & $\begin{array}{l}0.1518^{* *} \\
(0.0765)\end{array}$ \\
\hline $\begin{array}{l}\text { Institutional } \\
\text { quality } \\
\text { WGI-6 }\end{array}$ & $\begin{array}{l}0.0753^{*} \\
(0.0118)\end{array}$ & & & & \\
\hline $\begin{array}{l}\text { Institutional } \\
\text { quality } \\
\text { WGI-3 }\end{array}$ & & $\begin{array}{l}0.2040^{*} \\
(0.0401)\end{array}$ & & & \\
\hline $\begin{array}{l}\text { Regulatory quality } \\
\text { (RQ) }\end{array}$ & & & $\begin{array}{l}0.6107^{*} \\
(0.0996)\end{array}$ & & \\
\hline Rule of law (RL) & & & & $\begin{array}{l}0.5331^{*} \\
(0.1369)\end{array}$ & \\
\hline $\begin{array}{l}\text { Control of } \\
\text { Corruption (CC) }\end{array}$ & & & & & $\begin{array}{l}0.5999^{*} \\
(0.1348)\end{array}$ \\
\hline $\begin{array}{l}\begin{array}{l}\text { Hansen } \\
\text { value }]\end{array} \\
\text { Test }[\mathrm{P}- \\
\end{array}$ & 1.000 & 0.999 & 1.000 & 0.999 & 1.000 \\
\hline \multirow{2}{*}{$\begin{array}{l}\text { ABm2 [P-value] } \\
\text { Observations }\end{array}$} & 0.157 & 0.137 & 0.188 & 0.159 & 0.099 \\
\hline & 65 & 65 & 65 & 65 & 65 \\
\hline \multicolumn{6}{|c|}{$\begin{array}{l}\text { Note: The data sample ranges from } 1999 \text { to } 2018 \text { with } 5 \text {-year non-overlapping averages. All } \\
\text { variables are in log form except the KAOPEN index and institutional quality indicators. One-step } \\
\text { robust system GMM dynamic panel estimator of Arellano and Bond (1991) is used for estimation. } \\
\text { Robust standard errors are presented in parentheses; *, } * * \text { and }{ }^{* * *} \text { indicate significance at } 1 \% \text {, } \\
5 \% \text {, and } 10 \% \text { levels, respectively. }\end{array}$} \\
\hline
\end{tabular}

\subsection{Interpretations of Empirical Results}

Table 3.1-A shows the system GMM estimates with portfolio equity capital flows as a dependent variable. The coefficient on initial GDP per capita is statistically significant at $5 \%$ level with a positive sign in all regressions. The Worldwide governance indicators, including WGI-6, WGI-3, RL, and CC, are all found to be generally insignificant. However, RQ is statistically significant with a negative 


\section{Review of Economics and Development Studies, Vol. 6 (2) 2020, 461-470}

coefficient, which means that the strict regulatory framework discourages cross border capital flows. The credit variable is statistically significant at $1 \%$ level, with a positive coefficient in all the regressions. The coefficient of credit ranges from 1.88 to 2.02 indicates that a one percent upsurge in financial sector development will lead to increase portfolio equity capital flows by 1.88 to 2.02 percent or vice versa. It implies that portfolio investment flows are affected by the level of financial sector development in a state. The institutional quality cannot explain the Lucas Paradox adequately in case of portfolio equity capital flows. Portfolio flows are usually short-term investment inflows to earn quick returns in the stock markets. So, only the well-functioning stock markets and the established banking sector are considered important by the foreign investors.

In other words, short-term investors only consider financial sector development and overlook the institutional quality of the host country. The reason for the insignificant impact of institutions may be the weaker institutional structures in the developing countries (Peres et al. 2018). The KAOPEN index is weakly significant only in the last two regressions, while schooling remains statistically insignificant throughout. The $p$-value of the Hansen test is almost one in each regression, which shows that the null hypothesis about the validity of the instruments cannot be rejected. The $p$-value of ABm2 test indicates that we fail to reject the null hypothesis of no second-order serial correlation at a $5 \%$ level in all the regressions. The absence of second-order serial correlation illustrates that the estimators are efficient and consistent. The robust standard errors are computed, so there is no heteroscedasticity problem in the empirical analysis.

Table 3.1-B shows the system GMM estimates with FDI inflows as a dependent variable. All the WGI institutional quality measures are positive and significant at $1 \%$ level, reflecting the strong positive influence of institutions on FDI inflows. The individual WGI indicators comprising RL, RQ, and $\mathrm{CC}$ are also found to be significant at one percent level. It means that better governance with better law enforcement, reasonable regulatory quality, and a minimum level of corruption attracts FDI flows from abroad. FDI inflows are the long-term capital inflows in which investors evaluate the institutional quality of the host economy. The influx of foreign direct investment is affected by institutional quality because non-corrupt and transparent institutional structures incentivize foreign direct investors. Dunning (1988), Azam, Nawaz and Riaz (2019), and Shittu, Hassan, and Nawaz (2018) declare that the institutions are one of the important factors affecting FDI inflows. A poor institutional system impedes FDI and acts as a tax by raising the costs of FDI (Buchanan et al. 2012). Foreign investors are unwilling to bring FDI to the countries with fragile institutional structures encouraging red-tapism, corruption, and nepotism because these factors raise the cost of doing business (Mengistu \& Adhikary, 2011). The control variables, including initial GDP per capita, schooling, and KAOPEN, are found to be insignificant in all the regressions. The Hansen test $p$-value is almost one in each regression, which reveals the validity of instruments. The absence of second-order serial correlation is depicted by the statistically insignificant $p$-values of the ABm2 test in all the regressions. The absence of second-order serial correlation elucidates that the estimators are efficient and consistent. The robust GMM estimates give standard errors adjusted for heteroscedasticity. Hence, the estimates are not the victim of heteroscedasticity problem in our empirical analysis.

\section{Conclusion and Policy}

According to the neoclassical theory of capital flows, capital should flow from the rich countries towards poor countries. However, in reality, capital does not flow from the high income to low-income nations. This contradiction is named as the Lucas paradox. According to Alfaro, Kalemli-Ozcan, \& Volosovych, the Lucas paradox can be completely explained by institutional quality. This study empirically evaluates the role of institutional quality in explaining the Lucas paradox. A panel data set 


\section{Review of Economics and Development Studies, Vol. 6 (2) 2020, 461-470}

for 17 EMEs is utilized for the period 1999-2018. The system GMM estimation results suggest that the Lucas paradox is explained by the institutional quality in case of FDI flows.

But contrary to the AKV findings, our estimates suggest that the institutions do not explain the portfolio equity capital flows. The portfolio equity flows in the emerging markets are determined by the financial sector development. Considering our empirical findings, we cast doubts on AKV's findings and partially agree with the notion that the institutions can explain the Lucas paradox. Our findings also suggest that the financial flows to the emerging markets are sensitive to the nature of capital flows. The portfolio capital inflows are influenced by financial sector development, while foreign direct investment inflows are affected by institutional quality. The short-term nature of portfolio inflows also incentivizes foreign investors to gain quick returns by focusing on the financial sector and ignoring the quality of institutions in the host country. The long-term nature of FDI inflows induces investors to think about law enforcement, government stability, corruption, regulatory ability, and property rights protection. Hence FDI is affected by the institutional quality in the host economy.

The policymakers should consider the nature of capital inflows. The short-term portfolio equity inflows cause macroeconomic volatility but also help to remove the scarcity of capital for the immediate projects. The financial system should be developed and modernized to a cautious influx of portfolio investment. The sophisticated banking structure with vibrant stock markets can help to attract foreign capital, especially portfolio equity flows. FDI inflows are expedient, stable, and the least volatile type of inflows by nature, which can provide long-term benefits, including economies of scale, innovations, and technological diffusion. So, the long-term and less volatile capital flows like FDI are the most advantageous for EMEs. The policies should be designed to entice long-term foreign capital flows through better institutions, modern infrastructure, tax rebates and free trade industrial zones in the wake of financial globalization.

\section{References}

Acemoglu, D., Johnson, S., \& Robinson, J. A. (2005). Institutions as a fundamental cause of long-run growth. Handbook of economic growth, 1, 385-472.

Ahmed, S., \& Zlate, A. (2014). Capital flows to emerging market economies: A brave new World?. Journal of International Money and Finance, 48, 221-248.

Akhtaruzzaman, M., Berg, N., \& Hajzler, C. (2017). Expropriation risk and FDI in developing countries: Does return of capital dominate return on capital?. European Journal of Political Economy, 49, 84-107.

Albuquerque, R. (2003). The composition of international capital flows: risk sharing through foreign direct investment. Journal of International Economics, 61(2), 353-383.

Alfaro, L. (2003). Foreign direct investment and growth: Does the sector matter. Harvard Business School, 2003, 1-31.

Alfaro, L., Kalemli-Ozcan, S., \& Volosovych, V. (2007). Capital flows in a globalized world: The role of policies and institutions. In Capital controls and capital flows in emerging economies: Policies, practices and consequences (pp. 19-72). University of Chicago Press.

Alfaro, L., Kalemli-Ozcan, S., \& Volosovych, V. (2008). Why doesn't capital flow from rich to poor countries? An empirical investigation. The Review of Economics and Statistics, 90(2), 347-368.

Arellano, M., \& Bond, S. (1991). Some tests of specification for panel data: Monte Carlo evidence and an application to employment equations. Review of Economic Studies, 58, 277-297.

Arellano, M., \& Bover, O. (1995). Another look at the instrumental variable estimation of errorcomponents models. Journal of Econometrics, 68(1), 29-51.

Atiq-ur- Rehman, M., \& Hayat, M. A. (2017). Capital Account Liberalization and Economic Growth: 


\section{Review of Economics and Development Studies, Vol. 6 (2) 2020, 461-470}

Evidence from Emerging Market Economies. Pakistan Economic and Social Review, 55(1), 271285.

Azam, M. Nawaz, M. A., \& Riaz, M. (2019). Does corruption and terrorism affect foreign direct inflows into Pakistan? Journal of Managerial Sciences, 13(2), 85-97.

Azémar, C., \& Desbordes, R. (2013). Has the Lucas Paradox been fully explained?. Economics Letters, 121(2), 183-187.

Beck, T., Demirgüç-Kunt, A., \& Levine, R. (2010). Financial institutions and markets across countries and over time: The updated financial development and structure database. The World Bank Economic Review, 24(1), 77-92.

Buchanan, B. G., Le, Q. V., \& Rishi, M. (2012). Foreign direct investment and institutional quality: Some empirical evidence. International Review of financial analysis, 21, 81-89.

Byrne, J., \& Fiess, N. (2011). International Capital Flows to Emerging and Developing Countries: National and Global Determinants (No. 2011-03). Scottish Institute for Research in Economics (SIRE).

Caselli, F., \& Feyrer, J. (2007). The marginal product of capital. The quarterly journal of economics, 122(2), 535-568.

Chinn, M D. and Ito, H. (2006), What Matters for Financial Development? Capital Controls, Institutions, and Interactions, Journal of Development Economics, Volume 81(1), 163-192.

Daude, C., \& Fratzscher, M. (2008). The pecking order of cross-border investment, Journal of International Economics, 74(1), 94-119.

Daude, C., \& Stein, E. (2007). The quality of institutions and foreign direct investment. Economics \& Politics, 19(3), 317-344.

Dunning J. H. (1988). The eclectic paradigm of international production: a restatement and some possible extensions. Journal of International Business Studies 19(1):1-31

Edison, H. J., \& Warnock, F. E. (2008). Cross-border listings, capital controls, and equity flows to emerging markets. Journal of International Money and Finance, 27(6), 1013-1027.

Eichengreen, B., \& Park, Y. C. (2003). Why has there been less financial integration in Asia than in Europe?. Institute of European Studies, UC Berkeley.

Faria, A., \& Mauro, P. (2009). Institutions and the external capital structure of countries. Journal of International Money and Finance, 28(3), 367-391.

Faria, A., \& Mauro, P. (2009). Institutions and the external capital structure of countries. Journal of International Money and Finance, 28(3), 367-391.

Gertler, M., \& Rogoff, K. (1990). North-South lending and endogenous domestic capital market inefficiencies. Journal of monetary Economics, 26(2), 245-266.

Ghosh, A. R., Qureshi, M. S., Kim, J. I., \& Zalduendo, J. (2014). Surges. Journal of International Economics, 92(2), 266-285.

Göktan, M. G. (2015). On the explanation of the Lucas Paradox. Economics Letters, 137, 109-113.

Goldin, I., \& Reinert, K. (2007). Globalization for development: trade, finance, aid, migration, and policy (No. 52676, pp. 1-332). The World Bank.

Gourinchas, P. and O. Jeanne (2006). The elusive gains from international financial integration. Review of Economic Studies 73 (3): 715-741.

Hall, R. E., \& Jones, C. I. (1999). Why do some countries produce so much more output per worker than others?. The quarterly journal of economics, 114(1), 83-116.

Hernández, F. (1988). Globalization through work projects. Pedagogy notebooks, 155 , 54-59.

Hsieh, C. T., \& Klenow, P. J. (2009). Misallocation and manufacturing TFP in China and India. The Quarterly journal of economics, 124(4), 1403-1448.

Ju, J., \& Wei, S. J. (2014). A solution to two paradoxes of international capital flows. Economic and 


\section{Review of Economics and Development Studies, Vol. 6 (2) 2020, 461-470}

Political Studies, 2(1), 3-43.

Kose, M. A., Prasad, E. S., \& Terrones, M. E. (2003). How does globalization affect the synchronization of business cycles?. American Economic Review, 93(2), 57-62.

Lucas, R. E. (1990). Why doesn't capital flow from rich to poor countries?. The American Economic Review, 80(2), 92-96.

Martin, C. A. (2018). Does Financial Liberalization Matter on Capital Flows and Economic Growth?: Evidence from Asian Economies (Doctoral dissertation, The University of Tokyo).

Mengistu, A. A., \& Adhikary, B. K. (2011). Does good governance matter for FDI inflows? Evidence from Asian economies. Asia Pacific business review, 17(3), 281-299.

Méon, P. G., \& Sekkat, K. (2005). Does corruption grease or sand the wheels of growth?. Public choice, 122(1-2), 69-97.

Monge-Naranjo, A., Sánchez, J. M., \& Santaeulalia-Llopis, R. (2019). Natural resources and global misallocation. American Economic Journal: Macroeconomics, 11(2), 79-126.

North, D. (1990). Institutions. Journal of economic perspectives, 5(1), 97-112.

Parente, S. L., \& Prescott, E. C. (1991). Technology adoption and growth (No. w3733). National Bureau of Economic Research.

Peres, M., Ameer, W., \& Xu, H. (2018). The impact of institutional quality on foreign direct investment inflows: evidence for developed and developing countries. Economic research-Ekonomska istraživanja, 31(1), 626-644.

Reinhart, C. M., \& Rogoff, K. S. (2004). Serial default and the" paradox" of rich-to-poor capital flows. American Economic Review, 94(2), 53-58.

Rodrik, D. (2000). Institutions for high-quality growth: what they are and how to acquire them. Studies in comparative international development, 35(3), 3-31.

Shittu, W. O., Hassan, S, \& Nawaz, M. A. (2018). The nexus between external debt, corruption and economic growth: Evidence from five SSA countries. African Journal of Economic and Management Studies, 9(3), 319-334.

Stockman, A. C. (1988). On the roles of international financial markets and their relevance for economic policy. Journal of Money, Credit and Banking, 20(3), 531-549. 